\title{
How the U.S. Sport Performance Apparel Industry Sizes Up to Female Plus Bodies
}

\author{
Susan L. SOKOLOWSKI ${ }^{\star 1}$, Jessie SILBERT ${ }^{1}$, Linsey GRIFFIN² \\ ${ }^{1}$ University of Oregon, Portland, OR, USA; \\ 2 University of Minnesota, St. Paul, MN, USA
}

https://doi.org/10.15221/19.222

\begin{abstract}
In the United States, about $68 \%$ of the female population is greater than a size 14 , or plus size [1]. This demographic represents a $\$ 21.4$ billion industry [1]. Over the last five years, there has been a movement in the U.S. sport performance apparel industry to manufacture products for this body type, which historically has not been considered "athletic." As there is a lack of accessible measurements and sizing standardization for plus sizes, companies have developed their own unique systems, often graded from existing "sample sizes" (often a size small $4 / 6$ or medium $8 / 10$ ) or developed from old plus size standards (e.g., ASTM) [2]. As a result, plus size products in the U.S are inconsistently and unreliably sized. This challenge not only affects consumer satisfaction, but it also affects retailers and the environment. As an example, retailers scrap more than $25 \%$ of their returns, which can contribute to over five billion pounds in landfill each year [3]. The intent of this pilot study was to understand how well a sample of plus size bodies fit into the top three U.S. sport performance apparel companies' size charts. Sixty-five 3D body scans of plus size women, who self-identified as size $18 \mathrm{~W}$, were analyzed to determine how their chest/bust, waist and hip measures compared to the top three companies' sizing schemes. The companies included Nike, Adidas and Under Armour. Findings established that there are opportunities to: initiate a larger study to understand a more comprehensive set of bodies/measures, improve grading and size charts, develop relevant dress forms and product creation for this evolving demographic.
\end{abstract}

Key Words: Athletic apparel, plus sizes, sizing, anthropometric measures.

\section{Introduction}

What may be surprising, is that the market concept of "plus size" has been around since 1914 [4]. Today, sixty-eight percent of the U.S. adult female population-about 83,000,000-have been reported to be larger than a size 14, or plus size [5], [6]. Maternity and lingerie designer Lena Bryant and her engineer husband Albert Malsin began their journey of developing plus sized products, after conducting their own data collection of female proportions from 204,500 insurance company and personal clients [4]. Through their study, Bryant and Malsin found, that over half of their subjects were "women of ample figures" - providing a new market opportunity [4]. Their company was named Lane Bryant and has been in business for the last 105 years [4]. Today, the plus size demographic represents a $\$ 21.4$ billion industry [1].

Despite historical activity in the fashion industry to provide plus sizes, the sports performance apparel industry is rather new over the last five years, to manufacturing products for plus size bodies. However, this market segment is growing tremendously. Plus size brands have increased their activewear products by $77 \%$ in 2018 [7]. This pilot study explored how well a sample of plus size bodies actually fit into the top three U.S. athletic apparel companies' plus sizes, as defined by their online size charts.

\section{Background and Framework}

\subsection{Top 3 sport performance brands in the U.S.}

According to CNBC (2019), the top three sport performance apparel brands in the U.S are Nike, Adidas and Under [8]. Figure 1 depicts market share of the top brands[8].

\footnotetext{
*ssokolow@uoregon.edu
} 
Figure 1. Top sportswear market share in the U.S., by brand [8].

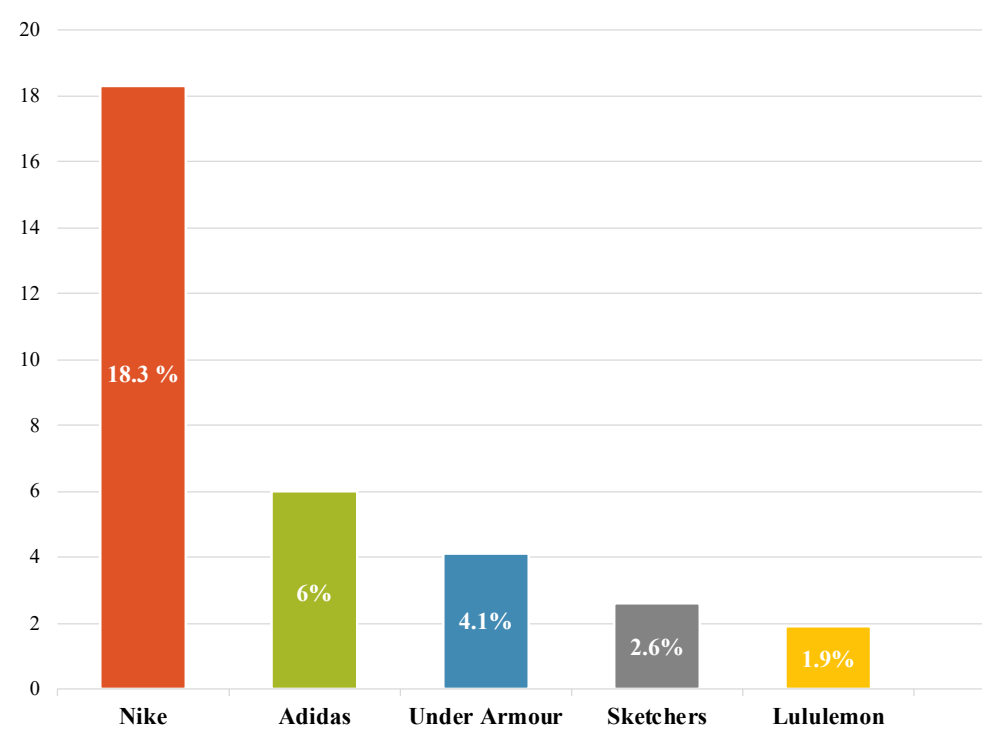

Nike, a $\$ 39.12$ billion company, leads in the U.S. market with 18.3 percent share [8], [9]. Adidas ranks second with 6 percent share, and is worth $\$ 25.07$ billion [8], [9] . In third place is Under Armour, who has 4.1 percent share and is worth $\$ 5.9$ billion [8], [9] . While other companies make up the remainder of the U.S. market, like Sketchers and Lululemon, focus for this pilot study was on the top three brands. Additionally, at this time, Lululemon does not manufacture a plus size assortment.

\subsection{Plus size charts for the top three sport performance brands}

From the three identified sports brands with the largest U.S. market share, plus size and measurement information were acquired on-line [10]-[13]. In the U.S. sport performance industry, plus sizes are identified as alpha sizes $1 \mathrm{X}$ and higher and/or $16 \mathrm{~W}$ and higher. Size and measurement charts are presented in Tables 1-3, by brand.

Table 1. Nike plus sizes and measurements [10].

\begin{tabular}{c|l|l|l|l}
\hline Alpha Size & Num. Size & Bust & Waist & Hip \\
\hline $1 X$ & $16 W-18 W$ & $45^{\prime \prime}-49^{\prime \prime}$ & $41 "-45^{\prime \prime}$ & $46 "-50 "$ \\
\hline $2 X$ & $20 W-22 W$ & $49 "-53^{\prime \prime}$ & $45^{\prime \prime}-49^{\prime \prime}$ & $50 "-54 "$ \\
\hline $3 X$ & $24 W-26 W$ & $53 "-57 "$ & $49 "-53 "$ & $54 "-58 "$ \\
\hline
\end{tabular}

Table 2. Adidas plus sizes and measurements [11], [12].

\begin{tabular}{c|l|l|l|l}
\hline Alpha Size & Num. Size & Bust & Waist & Hip \\
\hline $1 \mathrm{X}$ & ${ }^{*} 16 \mathrm{~W}-18 \mathrm{~W}$ & $41{ }^{\prime}-44.5 "$ & $35 "-38.5 "$ & $43.5 "-47 "$ \\
\hline $2 \mathrm{X}$ & ${ }^{*} 20 \mathrm{~W}-22 \mathrm{~W}$ & $45 "-48.5 "$ & $39 "-42.5 "$ & $47.5 "-51 "$ \\
\hline $3 \mathrm{X}$ & ${ }^{*} 24 \mathrm{~W}-26 \mathrm{~W}$ & $49 "-52.5 "$ & $43 "-46.5 "$ & $51.5 "-55 "$ \\
\hline $4 \mathrm{X}$ & ${ }^{*} 28 \mathrm{~W}-30 \mathrm{~W}$ & $53 "-56.5 "$ & $47 "-50.5 "$ & $55.5 "-59 "$ \\
\hline
\end{tabular}

*Numeric sizes are assumed, based upon nomenclature from competitor brands. The Adidas website does not assign numeric sizes

Table 3. Under Armor plus sizes and measurements [13].

\begin{tabular}{c|l|l|l|l}
\hline Alpha Size & Num. Size & Bust & Waist & Hip \\
\hline $1 \mathrm{X}$ & $16 \mathrm{~W}-18 \mathrm{~W}$ & $44^{\prime \prime}-47^{\prime \prime}$ & $39 "-43^{\prime \prime}$ & $47 "-50 "$ \\
\hline $2 \mathrm{X}$ & $20 \mathrm{~W}-22 \mathrm{~W}$ & 48 --51" $^{\prime \prime}$ & $44^{\prime \prime}-48^{\prime \prime}$ & $51 "-54 "$ \\
\hline $3 \mathrm{X}$ & $24 \mathrm{~W}-26 \mathrm{~W}$ & $52 "-55^{\prime \prime}$ & $49 "-53^{\prime \prime}$ & $55 "-58^{\prime \prime}$ \\
\hline
\end{tabular}




\subsection{Size and measurement inconsistency}

It is important to note that none of three brands have consistent measurements between their plus sizes. Typically in the fashion industry, measurements between brands are one to two inches different, but in the sports performance industry, they are more drastic. For example, when comparing bust measures between the three major brands, for size $1 \mathrm{X}(16 \mathrm{~W}-18 \mathrm{~W})$, they range between 41 to 49 inches (8-inch range). Examining waist and hip sizes, large measurement ranges also exist between all brands. Tables 4, 5 and 6 outline the measurement inconsistencies and ranges, by bust, waist and hip.

Table 4. Top three sport performance brand plus size bust measurement inconsistencies [10]-[13].

\begin{tabular}{|c|c|c|c|c|c|}
\hline Alpha Size & Num. Size & Nike Bust & Adidas Bust & UA Bust & Range \\
\hline $1 \mathrm{X}$ & 16W-18W & 45"-49" & $41 "-44.5 "$ & 44"-47" & 41"-49" \\
\hline $2 X$ & $20 \mathrm{~W}-22 \mathrm{~W}$ & 49"-53" & $45 "-48.5 "$ & 48"-51" & $45 "-53 "$ \\
\hline $3 X$ & $24 \mathrm{~W}-26 \mathrm{~W}$ & 53"-57" & 49"-52.5" & $52 "-55 "$ & $49 "-57 "$ \\
\hline $4 X$ & $28 \mathrm{~W}-30 \mathrm{~W}$ & NA & $53 "-56.5 "$ & NA & $53 "-56.5 "$ \\
\hline
\end{tabular}

Table 5. Top three sport performance brand plus size waist measurement inconsistencies [10]-[13]

\begin{tabular}{|c|c|c|c|c|c|}
\hline Alpha Size & Num. Size & Nike Waist & Adidas Waist & UA Waist & Range \\
\hline $1 \mathrm{X}$ & 16W-18W & $41 "-45 "$ & $35 "-38.5 "$ & 39"-43" & $35 "-45 "$ \\
\hline $2 X$ & $20 \mathrm{~W}-22 \mathrm{~W}$ & $45 "-49 "$ & $39 "-42.5 "$ & $44 "-48 "$ & $39 "-49 "$ \\
\hline $3 X$ & $24 \mathrm{~W}-26 \mathrm{~W}$ & 49"-53" & $43 "-46.5 "$ & 49"-53" & 43"-53" \\
\hline $4 X$ & $28 \mathrm{~W}-30 \mathrm{~W}$ & NA & $47 "-50.5 "$ & NA & $47 "-50.5 "$ \\
\hline
\end{tabular}

Table 6. Top three sport performance brand plus size hip measurement inconsistencies [10]-[13].

\begin{tabular}{|c|c|c|c|c|c|}
\hline Alpha Size & Num. Size & Nike Hip & Adidas Hip & UA Hip & Range \\
\hline $1 X$ & $16 \mathrm{~W}-18 \mathrm{~W}$ & $46 "-50 "$ & $43.5 "-47 "$ & 47"-50" & $43.5 "-50 "$ \\
\hline $2 X$ & $20 \mathrm{~W}-22 \mathrm{~W}$ & 50"-54" & $47.5 "-51 "$ & 51"-54" & $47.5 "-54 "$ \\
\hline $3 X$ & $24 \mathrm{~W}-26 \mathrm{~W}$ & 54"-58" & 51.5"-55" & 55"-58" & $51.5 "-58 "$ \\
\hline $4 X$ & $28 \mathrm{~W}-30 \mathrm{~W}$ & NA & $55.5 "-59 "$ & NA & $55.5 "-59 "$ \\
\hline
\end{tabular}

There are also measurement overlaps between core (non-plus) size XXL and plus sizes $16 \mathrm{~W}$-18W within a brand. Measurement overlaps are where there are two sizes produced by the same company and they share the same or similar measures. For example Nike's core size 20-22 (XXL) has a bust measurement range of 44.5 to 48.5 inches - which overlaps with Nike's plus size of $16 \mathrm{~W}-18 \mathrm{~W}(1 \mathrm{X})$ that has a bust measurement range of 45 to 49 inches. The same overlaps occur with waist and hip measures, for all brands. They are presented in Tables 7, 8 and 9.

Table 7. Measurement overlaps: Nike core size XXL vs. Nike plus size 16W-18W [10].

\begin{tabular}{c|c|c|c|c}
\hline Alpha Size & Num. Size & Nike Bust & Nike Waist & Nike Hip \\
\hline XXL & $20-22$ (core) & $44.5 "-48.5 "$ & $38.5 "-42.5 "$ & $47 "-50 "$ \\
\hline $1 X$ & $16 W-18 W$ (plus) & $45 "-49 "$ & $41 "-45 "$ & $46 "-50 "$ \\
\hline
\end{tabular}

Table 8. Measurement overlaps: Adidas core size XXL vs. Adidas plus size 16W-18W [11], [12].

\begin{tabular}{c|c|c|c|c}
\hline Alpha Size & Num. Size & Adidas Bust & Adidas Waist & Adidas Hip \\
\hline$X X L$ & $20-22$ (core) & $43.5 "-46.5 "$ & $37.5 "-41 "$ & $46.5 "-49 "$ \\
\hline $1 X$ & ${ }^{\prime \prime} 16 \mathrm{~W}-18 \mathrm{~W}$ (plus) & $41 "-44.5 "$ & $35 "-38.5 "$ & $43.5 "-47 "$ \\
\hline
\end{tabular}

*Numeric sizes are assumed, based upon nomenclature from competitor brands. The Adidas website does not assign numeric sizes.

Table 9. Measurement overlaps: Under Armour core size XXL vs. Under Armour plus size 16W-18W [13].

\begin{tabular}{c|c|c|c|c}
\hline Alpha Size & Num. Size & UA Bust & UA Waist & UA Hip \\
\hline XXL & $20-22$ (core) & $45^{\prime \prime}-46.5 "$ & $38 "-39.5 "$ & $47 "-48.5 "$ \\
\hline $1 X$ & $16 W-18 W$ (plus) & $44 "-47^{\prime \prime}$ & $39 "-43^{\prime \prime}$ & $47 "-50 "$ \\
\hline
\end{tabular}


Inconsistent and duplicate sized products not only affect the consumer and how they make purchasing choices, but also affect retailers financially and environmentally. For example, the Wall Street Journal reported that on-line returns average around 30 percent, because of fit [14], [15]. In addition, the Retail Equation and National Retail Federation reported that $\$ 260.5$ billion in returns are made globally [14]. They quoted, "if merchandise returns were a corporation, it would rank \#3 on the Fortune 500 list" [14], [16]. Returns also affect the environment, where retailers discard more than 25 percent of their returns, which accounts for more than 5 billion pounds of additional landfill per year [3], [14] . Given the measurement inconsistency between brands, it is curious to understand how actual plus size consumers fit into the top three brand sizing charts and if an effort could be made to improve sellthrough and environmental impact.

This pilot study examined how a small sample of self-identified plus size $18 \mathrm{~W}$ women fit into the leading sport performance brand sizing charts. It is anticipated that the results of this study will help identify which retailers are fitting plus sizes better and make recommendations for future apparel sizing and product development for this growing demographic.

\section{Methodology}

The goal of this paper was to understand how actual plus size women fit into the top three U.S. plus size sport performance brand size charts. For purposes of the pilot study, it was determined to focus on one plus size only, to fully understand the complexities women face within a particular size.

Women who self-identified as plus size $18 \mathrm{~W}$ participated in the study. Subjects were 3D body scanned, and bust, waist and hip measurements were collected, using AnthroScan ${ }^{\mathrm{TM}}$ software. The bust measurement was defined as the largest circumferential measurement of the bust taken parallel to the floor. The waist circumference measurement was taken at the natural waist crease on the torso, also parallel to the floor. The hip circumference was taken at the widest portion of the bottom (parallel). All measurements were taken in inches to match the unit of measure from each brand's size chart.

From each subject's collected bust, waist and hip measures, they were matched to each of the three brand's size $16 \mathrm{~W}-18 \mathrm{~W}(1 \mathrm{X})$ charts to see if and how they fit. The following questions were answered:

1. Does the $3 \mathrm{D}$ scan fit within all of size $16 \mathrm{~W}-18 \mathrm{~W}(1 \mathrm{X})$ the bust, waist and hip measurement ranges, for each brand? In order to fit perfectly in the brand's size, the subject had to completely fit in, each measure of the size range provided.

If no to \#1:

2. Does the 3D scan fit into the size $16 \mathrm{~W}-18 \mathrm{~W}(1 \mathrm{X})$ bust and waist measurement ranges, for each brand?

3. Does the 3D scan fit into the size 16W-18W (1X) bust and hip measurement ranges, for each brand?

4. Does the 3D scan fit into the size $16 \mathrm{~W}-18 \mathrm{~W}$ (1X) waist and hip measurement ranges, for each brand?

5. Does the 3D scan fit into the size $16 \mathrm{~W}-18 \mathrm{~W}$ (1X) bust-only measurement range, for each brand?

6. Does the 3D scan fit into the size $16 \mathrm{~W}-18 \mathrm{~W}(1 \mathrm{X})$ waist-only measurement range, for each brand?

7. Does the 3D scan fit into the size 16W-18W (1X) hip-only measurement range, for each brand?

8. Does the 3D scan not fit into any of size $16 \mathrm{~W}-18 \mathrm{~W}(1 \mathrm{X})$ measurement ranges, for each brand?

From the data matches, percentages were calculated for each brand.

\section{Results}

3D scans from 65 plus size female subjects, with a mean age of 38.5 years were analyzed for the study. Subjects identified as a size $18 \mathrm{~W}$ and one of the following races: African American/Black $(46.2 \%)$, Asian/Pacific Islander (1.5\%), Caucasian/White (41.5\%), Latinx/Hispanic (4.6\%), Native American $(1.5 \%)$ and Other (4.6\%). Scans were collected with a Human Solutions VITUS Smart XXL 3D LASER Body Scanner and 3DMD scanner. Basic statistics (mean, median and range) of the subject's measurements are presented in Table 10. 
Table 10. Subject 3D scan measures.

\begin{tabular}{c|c|c|c}
\hline Self-Identified & Bust & Waist & Hip \\
Size 18W $(\mathrm{n}=65)$ & $45.83 "$ & $42.58 ”$ & $49.99^{\prime \prime}$ \\
Mean & $45.92 "$ & $43.07 "$ & $49.51 "$ \\
Median & $33.46 "-63.46 "$ & $30.12 "-55.09 "$ & $41.977^{\prime \prime}-63.23 "$ \\
Range & & \\
\hline
\end{tabular}

From each brand's 16W-18W (1X) size and measurements (Tables 1-3), bust, waist and hip measurements from the 3D scans were matched. Tables 11-13 are the results of that analysis.

Table 11. Number of subjects that fit the Nike brand plus size $16 W-18 W(1 X)$.

\begin{tabular}{c|r|r|r|r|r|r|r|r}
\hline Size & \multicolumn{1}{|c|}{$\begin{array}{c}\text { All } \\
\text { Fit }\end{array}$} & $\begin{array}{c}\text { Bust \& } \\
\text { Waist } \\
\text { Fit }\end{array}$ & $\begin{array}{c}\text { Bust \& } \\
\text { Hip Fit }\end{array}$ & $\begin{array}{c}\text { Waist \& } \\
\text { Hip Fit }\end{array}$ & $\begin{array}{c}\text { Bust } \\
\text { Only Fit }\end{array}$ & $\begin{array}{c}\text { Waist } \\
\text { Only Fit }\end{array}$ & $\begin{array}{c}\text { Hip } \\
\text { Only } \\
\text { Fit }\end{array}$ & \multicolumn{1}{c}{$\begin{array}{c}\text { No } \\
\text { Fit }\end{array}$} \\
\hline $\mathbf{1 6 W}-\mathbf{1 8 W}$ & 2 & 4 & 4 & 2 & 13 & 0 & 12 & 28 \\
\cline { 2 - 9 }$(\mathbf{1 X )}$ & $3.08 \%$ & $6.15 \%$ & $6.15 \%$ & $3.08 \%$ & $20.00 \%$ & $0.00 \%$ & $18.46 \%$ & $43.08 \%$ \\
\hline
\end{tabular}

Table 12. Number of subjects that fit the Adidas brand plus size $16 W-18 W(1 X)$.

\begin{tabular}{c|r|r|r|r|r|r|r|r}
\hline \multirow{2}{*}{ Size } & \multicolumn{1}{|c|}{$\begin{array}{c}\text { All } \\
\text { Fit }\end{array}$} & $\begin{array}{c}\text { Bust \& } \\
\text { Waist } \\
\text { Fit }\end{array}$ & $\begin{array}{c}\text { Bust \& } \\
\text { Hip Fit }\end{array}$ & $\begin{array}{c}\text { Waist \& } \\
\text { Hip Fit }\end{array}$ & $\begin{array}{c}\text { Bust } \\
\text { Only Fit }\end{array}$ & $\begin{array}{c}\text { Waist } \\
\text { Only Fit }\end{array}$ & $\begin{array}{c}\text { Hip } \\
\text { Only } \\
\text { Fit }\end{array}$ & \multicolumn{1}{|c|}{$\begin{array}{c}\text { No } \\
\text { Fit }\end{array}$} \\
\hline \multirow{2}{16}{$\begin{array}{c}\text { 16W-18W } \\
(\mathbf{1 X )}\end{array}$} & 1 & 9 & 1 & 0 & 1 & 1 & 8 & 44 \\
\cline { 2 - 9 } & $1.54 \%$ & $13.85 \%$ & $1.54 \%$ & $0.00 \%$ & $1.54 \%$ & $1.54 \%$ & $12.31 \%$ & $67.69 \%$ \\
\hline
\end{tabular}

Table 13. Number of subjects that fit the Under Armour brand plus size $16 W-18 W(1 X)$.

\begin{tabular}{c|r|r|r|r|r|r|r|r}
\hline \multirow{2}{*}{ Size } & \multicolumn{1}{|c|}{$\begin{array}{c}\text { All } \\
\text { Fit }\end{array}$} & $\begin{array}{c}\text { Bust \& } \\
\text { Waist } \\
\text { Fit }\end{array}$ & $\begin{array}{c}\text { Bust \& } \\
\text { Hip Fit }\end{array}$ & $\begin{array}{c}\text { Waist \& } \\
\text { Hip Fit }\end{array}$ & $\begin{array}{c}\text { Bust } \\
\text { Only Fit }\end{array}$ & $\begin{array}{c}\text { Waist } \\
\text { Only Fit }\end{array}$ & $\begin{array}{c}\text { Hip } \\
\text { Only } \\
\text { Fit }\end{array}$ & \multicolumn{1}{|c|}{$\begin{array}{c}\text { No } \\
\text { Fit }\end{array}$} \\
\hline $\mathbf{1 6} \begin{array}{c}\text { 16W-18W } \\
(\mathbf{1 X )}\end{array}$ & 1 & 4 & 7 & 1 & 6 & 2 & 5 & 39 \\
\cline { 2 - 10 } & $1.54 \%$ & $6.15 \%$ & $10.77 \%$ & $1.54 \%$ & $9.23 \%$ & $3.08 \%$ & $7.69 \%$ & $60.00 \%$ \\
\hline
\end{tabular}

Sixty-one women $(93.85 \%)$ did not fit into any of the leading plus size sport performance brands size $16 \mathrm{~W}-18 \mathrm{~W}$. Only two subjects fit into Nike, one in Adidas, and one in Under Armour sizes 16W-18W (1X). In all cases the waist was most difficult to fit - as it was too small.

When subject 3D scan data were matched to the core size 20-22 (XXL), for all brands, four subjects fit into Nike, two in Adidas and zero in Under Armour sizes 16W-18W (1X). This was the size that had measurement overlaps with the size 16W-18W (1X). Tables 14-16 presents those results.

Table 14. Number of subjects that fit the Nike brand core size 20-22 (XXL).

\begin{tabular}{c|r|r|r|r|r|r|r|r}
\hline \multirow{2}{*}{ Size } & \multicolumn{1}{|c|}{$\begin{array}{c}\text { All } \\
\text { Fit }\end{array}$} & $\begin{array}{c}\text { Bust \& } \\
\text { Waist } \\
\text { Fit }\end{array}$ & $\begin{array}{l}\text { Bust \& } \\
\text { Hip Fit }\end{array}$ & $\begin{array}{l}\text { Waist \& } \\
\text { Hip Fit }\end{array}$ & $\begin{array}{c}\text { Bust } \\
\text { Only Fit }\end{array}$ & $\begin{array}{c}\text { Waist } \\
\text { Only Fit }\end{array}$ & $\begin{array}{c}\text { Hip } \\
\text { Only } \\
\text { Fit }\end{array}$ & \multicolumn{1}{|c|}{$\begin{array}{l}\text { No } \\
\text { Fit }\end{array}$} \\
\hline \multirow{2}{2}{$\mathbf{2 0 - 2 2}$} & 4 & 2 & 7 & 1 & 12 & 2 & 7 & 30 \\
\cline { 2 - 9 }$(\mathbf{X X L})$ & $6.15 \%$ & $3.08 \%$ & $10.77 \%$ & $1.54 \%$ & $18.46 \%$ & $3.08 \%$ & $10.77 \%$ & 46.15 \\
\hline
\end{tabular}

Table 15. Number of subjects that fit the Adidas brand core size 20-22 (XXL).

\begin{tabular}{c|r|r|r|r|r|r|r|r}
\hline \multirow{2}{*}{ Size } & \multicolumn{1}{|c|}{$\begin{array}{c}\text { All } \\
\text { Fit }\end{array}$} & $\begin{array}{c}\text { Bust \& } \\
\text { Waist } \\
\text { Fit }\end{array}$ & $\begin{array}{l}\text { Bust \& } \\
\text { Hip Fit }\end{array}$ & $\begin{array}{l}\text { Waist \& } \\
\text { Hip Fit }\end{array}$ & $\begin{array}{c}\text { Bust } \\
\text { Only Fit }\end{array}$ & $\begin{array}{c}\text { Waist } \\
\text { Only Fit }\end{array}$ & $\begin{array}{c}\text { Hip } \\
\text { Only } \\
\text { Fit }\end{array}$ & \multicolumn{2}{|c|}{$\begin{array}{c}\text { No } \\
\text { Fit }\end{array}$} \\
\hline \multirow{2}{20-22}{} & 2 & 1 & 2 & 1 & 11 & 3 & 5 & 40 \\
\cline { 2 - 9 }$(\mathbf{X X L})$ & $3.08 \%$ & $1.54 \%$ & $3.08 \%$ & $1.54 \%$ & $16.92 \%$ & $4.62 \%$ & $7.69 \%$ & $61.54 \%$ \\
\hline
\end{tabular}


Table 16. Number of subjects that fit the Under Armour brand core size 20-22 (XXL).

\begin{tabular}{c|r|r|r|r|r|r|r|r}
\hline Size & \multicolumn{1}{|c|}{$\begin{array}{c}\text { All } \\
\text { Fit }\end{array}$} & $\begin{array}{c}\text { Bust \& } \\
\text { Waist } \\
\text { Fit }\end{array}$ & $\begin{array}{c}\text { Bust \& } \\
\text { Hip Fit }\end{array}$ & $\begin{array}{c}\text { Waist \& } \\
\text { Hip Fit }\end{array}$ & $\begin{array}{c}\text { Bust } \\
\text { Only Fit }\end{array}$ & $\begin{array}{c}\text { Waist } \\
\text { Only Fit }\end{array}$ & $\begin{array}{c}\text { Hip } \\
\text { Only } \\
\text { Fit }\end{array}$ & \multicolumn{2}{|c}{$\begin{array}{c}\text { No } \\
\text { Fit }\end{array}$} \\
\hline $\mathbf{2 0 - 2 2}$ & 0 & 4 & 2 & 0 & 3 & 1 & 5 & 50 \\
\hline (XXL) & $0 \%$ & $6.15 \%$ & $3.08 \%$ & $0 \%$ & $4.62 \%$ & $1.54 \%$ & $7.69 \%$ & $76.92 \%$ \\
\hline
\end{tabular}

Since subjects self-identified their size, it was possible they vanity sized themselves. With that notion, measurement ranges (bust, waist, hip) were calculated for all plus sizes, for all three brands to determine if the subjects fit into the other sizes better. Tables 17-19 illustrates those results.

Table 17. Number of subjects that fit the Nike brand, by sizes larger than $16 W-18 W(1 X)$.

\begin{tabular}{|c|c|c|c|c|c|c|c|c|}
\hline Size & $\begin{array}{l}\text { All } \\
\text { Fit }\end{array}$ & $\begin{array}{c}\text { Bust \& } \\
\text { Waist } \\
\text { Fit }\end{array}$ & $\begin{array}{l}\text { Bust \& } \\
\text { Hip Fit }\end{array}$ & $\begin{array}{l}\text { Waist \& } \\
\text { Hip Fit }\end{array}$ & $\begin{array}{c}\text { Bust } \\
\text { Only Fit }\end{array}$ & $\begin{array}{c}\text { Waist } \\
\text { Only Fit }\end{array}$ & $\begin{array}{c}\text { Hip } \\
\text { Only } \\
\text { Fit }\end{array}$ & $\begin{array}{l}\text { No } \\
\text { Fit }\end{array}$ \\
\hline \multirow{2}{*}{$\begin{array}{c}20 W-22 W \\
(2 X)\end{array}$} & 0 & 0 & 4 & 6 & 4 & 8 & 11 & 32 \\
\hline & $0.00 \%$ & $0.00 \%$ & $6.15 \%$ & $9.23 \%$ & $6.15 \%$ & $12.31 \%$ & $16.92 \%$ & $49.23 \%$ \\
\hline \multirow{2}{*}{$\begin{array}{c}24 W-26 W \\
(3 X)\end{array}$} & 1 & 2 & 1 & 1 & 1 & 9 & 1 & 49 \\
\hline & $1.54 \%$ & $3.08 \%$ & $1.54 \%$ & $1.54 \%$ & $1.54 \%$ & $13.85 \%$ & $1.54 \%$ & $75.38 \%$ \\
\hline
\end{tabular}

Table 18. Number of subjects that fit the Adidas brand, by sizes larger than $16 W-18 W(1 X)$.

\begin{tabular}{|c|c|c|c|c|c|c|c|c|}
\hline Size & $\begin{array}{l}\text { All } \\
\text { Fit }\end{array}$ & $\begin{array}{c}\text { Bust \& } \\
\text { Waist } \\
\text { Fit }\end{array}$ & $\begin{array}{l}\text { Bust \& } \\
\text { Hip Fit }\end{array}$ & $\begin{array}{c}\text { Waist \& } \\
\text { Hip Fit }\end{array}$ & $\begin{array}{c}\text { Bust } \\
\text { Only Fit }\end{array}$ & $\begin{array}{l}\text { Waist } \\
\text { Only Fit }\end{array}$ & $\begin{array}{c}\text { Hip } \\
\text { Only } \\
\text { Fit }\end{array}$ & $\begin{array}{l}\text { No } \\
\text { Fit }\end{array}$ \\
\hline \multirow{2}{*}{$\begin{array}{c}20 W-22 W \\
(2 X)\end{array}$} & 0 & 4 & 5 & 1 & 9 & 3 & 7 & 36 \\
\hline & $0 \%$ & $6.15 \%$ & $7.69 \%$ & $1.54 \%$ & $13.85 \%$ & $4.62 \%$ & $10.77 \%$ & $55.38 \%$ \\
\hline \multirow{2}{*}{$\begin{array}{c}24 W-26 W \\
(3 X)\end{array}$} & 0 & 1 & 3 & 2 & 1 & 6 & 11 & 41 \\
\hline & $0 \%$ & $1.54 \%$ & $4.62 \%$ & $3.08 \%$ & $1.54 \%$ & $9.23 \%$ & $16.92 \%$ & $63.08 \%$ \\
\hline \multirow{2}{*}{$\begin{array}{c}28 W-30 W \\
(4 X)\end{array}$} & 1 & 2 & 1 & 1 & 0 & 11 & 0 & 49 \\
\hline & $1.54 \%$ & $3.08 \%$ & $1.54 \%$ & $1.54 \%$ & $0 \%$ & $16.92 \%$ & $0 \%$ & $75.38 \%$ \\
\hline
\end{tabular}

Table 19. Number of subjects that fit the Under Armour brand, by sizes larger than 16W-18W (1X).

\begin{tabular}{|c|c|c|c|c|c|c|c|c|}
\hline Size & $\begin{array}{l}\text { All } \\
\text { Fit }\end{array}$ & $\begin{array}{c}\text { Bust \& } \\
\text { Waist } \\
\text { Fit }\end{array}$ & $\begin{array}{l}\text { Bust \& } \\
\text { Hip Fit }\end{array}$ & $\begin{array}{c}\text { Waist \& } \\
\text { Hip Fit }\end{array}$ & $\begin{array}{c}\text { Bust } \\
\text { Only Fit }\end{array}$ & $\begin{array}{c}\text { Waist } \\
\text { Only Fit }\end{array}$ & $\begin{array}{c}\text { Hip } \\
\text { Only } \\
\text { Fit }\end{array}$ & $\begin{array}{l}\text { No } \\
\text { Fit }\end{array}$ \\
\hline \multirow{2}{*}{$\begin{array}{c}20 W-22 W \\
(2 X)\end{array}$} & 0 & 1 & 5 & 2 & 5 & 5 & 10 & 37 \\
\hline & $0.00 \%$ & $1.54 \%$ & $7.69 \%$ & $3.08 \%$ & $7.69 \%$ & $7.69 \%$ & $15.38 \%$ & $56.92 \%$ \\
\hline \multirow{2}{*}{$\begin{array}{c}24 W-26 W \\
(3 X)\end{array}$} & 1 & 3 & 1 & 0 & 1 & 9 & 1 & 49 \\
\hline & $1.54 \%$ & $4.62 \%$ & $1.54 \%$ & $0.00 \%$ & $1.54 \%$ & $13.85 \%$ & $1.54 \%$ & $75.38 \%$ \\
\hline
\end{tabular}

Surprisingly, only three more subjects were matched fully into a size - one fitting into a Nike size $24 \mathrm{~W}$ 26W (3X), one into an Adidas 28W-30W (4X), and a third into Under Armour's size 24W-26W (3X). For all brands when two girth measurements were in consideration it was more likely that the subject would fit bust \& waist or bust \& hip, with the waist \& hip measurements being the least likely to fit. 


\section{Summary and Conclusion}

For the top three sport performance apparel brands in the U.S. that produce plus size apparel, there is opportunity to improve how products are sized. Findings established that there is space to initiate a larger study, to: understand a more comprehensive set of bodies/measures, improve grading and size charts, develop relevant dress forms and product creation for this evolving demographic. With this work it is also important to consider a more diverse pool of subjects that better represent the U.S. market (e.g., Hispanic, African American and Asian). The waist is an obvious feature to improve upon and results depict that the plus size body is not an hour glass shape. Further exploration may also deem that one of the overlapping of sizes (16W-18W/1X and 20-22/XXL) could be eliminated from each brand, to diminish consumer confusion and improve business and sustainability metrics through SKU reduction. Given how the plus size demographic is growing, this work would help more women find apparel that fits bolster sales and decrease the number of returns from consumers.

\section{Reference}

[1] H. George-Parkin, "68\% of American Women Wear a Size 14 or Above," Racked, 05-Jun-2018. [Online]. Available: https://www.racked.com/2018/6/5/17380662/size-numbers-average-womanplus-market. [Accessed: 08-Sep-2019].

[2] D13 Committee, "Tables for Body Measurements for Plus Womens Figure Type, Size Range 14W20W," ASTM International.

[3] C. Reagan, "That sweater you don't like is a trillion-dollar problem for retailers. These companies want to fix it," CNBC, 12-Jan-2019. [Online]. Available:

https://www.cnbc.com/2019/01/10/growing-online-sales-means-more-returns-and-trash-forlandfills.html. [Accessed: 08-Sep-2019].

[4] F. C. Ingram, "Lane Bryant, Inc.," in International Directory of Company Histories, vol. 64, T. Grant and M. H. Ferrara, Eds. Detroit: St. James Press [u.a.], 2005, pp. 231-233.

[5] S. C. Dunn, "Women's Plus-size Apparel: Assessment of Clothing Size Charts Among National Retail Federation's 2015 Top 100 US Retailers," Washington State University Pullman, WA, 2016.

[6] United States Census Bureau, "U.S. and World Population Clock," United States Census Bureau. [Online]. Available: https://www.census.gov/popclock/. [Accessed: 08-Sep-2019].

[7] C. Yau, "Regular vs plus-size activewear assortments. What's new?," EDITED, 06-Dec-2018. .

[8] Statista, "Sportswear market share in the United States as of 2018, by company." CNBC Statista, 17-Apr-2019.

[9] Statista, "Sportswear / Sporting goods companies ranked by worldwide revenue in 2018 (in billion U.S. dollars)*." CNBC Statista, 08-Aug-2019.

[10] Nike, "Plus size chart," Nike.com Size Fit Guide - Women's Tops. [Online]. Available: https://www.nike.com/us/en_us/sfg/womens-tops-sizing-chart. [Accessed: 08-Sep-2019].

[11] "adidas Women's T-Shirt \& Jacket Size Chart," adidas US. [Online]. Available: https://www.adidas.com/us/help/size_charts. [Accessed: 08-Sep-2019].

[12] "adidas Women's Shorts \& Leggings Size Chart," adidas US. [Online]. Available: https://www.adidas.com/us/help/size_charts. [Accessed: 08-Sep-2019].

[13] "Under Armour Size Charts," Under Armour. [Online]. Available: https://www.underarmour.com/en-us/size-charts. [Accessed: 08-Sep-2019].

[14] S. L. Sokolowski, L. Griffin, and J. Silbert, "The Variability of U.S. Women's Plus Size Product Sizing and Self-Identified Size 18 Bodies," in Advances in Interdisciplinary Practice in Industrial Design, 2020, pp. 124-133.

[15] "Apparel retailers start 2016 with a 30\% return rate," Bold Metrics Blog, 05-Jan-2016. [Online]. Available: http://blog.boldmetrics.com/apparel-retailers-start-2016-with-a-30-return-rate/. [Accessed: 08-Sep-2019].

[16] L. Ewen, "How the future of fit could spell the end of retail returns," Retail Dive, 07-Jul-2016. [Online]. Available: https://www.retaildive.com/news/how-the-future-of-fit-could-spell-the-end-ofretail-returns/421972/. [Accessed: 08-Sep-2019]. 